\title{
Natural material adsorbed onto a polymer to enhance immune function
}

This article was published in the following Dove Press journal:

Drug Design, Development and Therapy

24 August 2012

Number of times this article has been viewed

\begin{abstract}
Ana Paula Barcelos
Reinaque ${ }^{\prime}$

Eduardo Luzía França ${ }^{2}$

Edson Fredulin Scherer ${ }^{3}$

Mayra Aparecida Côrtes'

Francisco José Dutra

Souto 4

Adenilda Cristina

Honorio-França ${ }^{5}$

'Post Graduate Program in Material Science, ${ }^{2}$ Institute of Biological and Health Science, Federal University of Mato Grosso, Barra do Garças, ${ }^{3}$ Post Graduate Program in Material Science, Institute of Biological and Health Science, Federal University of Mato Grosso, Pontal do Araguaia, ${ }^{4}$ Faculty of Medical Sciences, Federal University of Mato Grosso, Cuiabá, ${ }^{5}$ Institute of Biological and Health Science, Federal University of Mato Grosso, Pontal do Araguaia, MT, Brazil
\end{abstract}

Correspondence: Eduardo Luzía França Institute of Biological and Health Science, Federal University of Mato Grosso, BR 070, Km 05 CEP 78600-000,

Barra do Garças, MT, Brazil

Tel +5566340553I7

Fax +55 663402 III7

Email elfranca@ufmt.br
Background: In this study, we produced poly(ethylene glycol) (PEG) microspheres of different sizes and adsorbing a medicinal plant mixture, and verified their effect in vitro on the viability, superoxide production, and bactericidal activity of phagocytes in the blood.

Methods: The medicinal plant mixture was adsorbed onto PEG microspheres and its effects were evaluated by flow cytometry and fluorescence microscopy.

Results: Adsorption of the herbal mixture onto the PEG microspheres was achieved and the particles were internalized by phagocytes. PEG microspheres bearing the adsorbed herbal mixture stimulated superoxide release, and activated scavenging and microbicidal activity in phagocytes. No differences in functional activity were observed when the phagocytes were not incubated with PEG microspheres bearing the adsorbed herbal mixture.

Conclusion: This system may be useful for the delivery of a variety of medicinal plants and can confer additional protection against infection. The data reported here suggest that a polymer adsorbed with a natural product is a treatment alternative for enhancing immune function.

Keywords: natural product, polymer, adsorption, immune function, phagocytes

\section{Introduction}

There are a number of advantages associated with the development of plant-based drugs that can be administered in nanoscale doses, including enhancement of solubility and bioavailability, protection from toxicity, enhancement of pharmacological activity and stability, improved macrophage distribution in tissues, sustained delivery, and protection from physical and chemical degradation. ${ }^{1}$

Polymeric microparticles are systems with promising applications for the adsorption of nanodoses of phytopharmaceuticals and also promote controlled release of drugs or biologically active hydrophilic or hydrophobic substances. ${ }^{2}$ Poly(ethylene glycol) (PEG) microspheres are polymeric particles with the capacity to absorb organic compounds and are considered to be an important carrier system. ${ }^{3}$ The capacity of microspheres to adsorb organic compounds can be modified to improve their biological function. This topic is of great interest because microspheres have outstanding properties that are essential for biomedical applications, including solubility in water and organic solvents, lack of toxicity, and absence of antigenicity. ${ }^{4}$ PEG-drug conjugates are being studied for a variety of molecules, including drugs, peptides, and lipids. ${ }^{5-12}$ PEG-drug conjugates have several advantages, including prolonged residence time in the body, decreased degradation by metabolic enzymes, and reduction or elimination of protein immunogenicity. ${ }^{8}$ 
Improving the therapeutic properties of herbal compounds via their incorporation into microparticles is an important strategy for manufacturing drugs with lower toxicity, suppressing adverse reactions, and reducing the number and concentration of doses necessary for a therapeutic effect. ${ }^{13}$

In Brazilian ethnopharmacology, a popular mixture of seven plants has been shown to be useful for immune system enhancement as well as for increasing resistance to development of malignant cells. This herbal mixture includes extracts from the following plants: Orbignya Marti, Tabebuia avellanedae, Arctium lappa, Rosa centifolia, Maytenus ilicifolia, Vernonia condensata, and Thujae occidentalis. It has been demonstrated that this herbal mixture has the ability to activate oxidative mechanisms ${ }^{14}$ in phagocytosis and to have microbicidal activity. ${ }^{15}$

Macrophages play an important role in the body's defense mechanisms against infection. The functional activity of macrophages in various biological systems has been associated with enhanced immunomodulatory activity. ${ }^{16-19}$ Generation of free radicals has been reported to be an important mechanism for protecting the body during infection..$^{20}$ During oxidative stress, cellular mitochondrial and peroxisomal metabolism generates large amounts of the superoxide anion. ${ }^{16-21}$ The free radicals released are an important defense mechanism for the body, especially for infections of the gut. .7,18,22,23 $^{2}$

The literature has indicated that many plants can stimulate immune cells, so are promising in the treatment of infections. ${ }^{24}$ Plants are a source of traditional medicines, with chemical substances that have potentially useful properties for modulation of the immune system. ${ }^{25}$ Immunostimulatory and immunosuppressive activities have been investigated in a large number of plants and their isolated constituents. ${ }^{16,26}$ These studies have attracted worldwide attention as an alternative to traditional treatment methods. ${ }^{27}$ The aim of this study was to adsorb a medicinal plant mixture onto PEG microspheres and to verify the in vitro immunomodulatory effects of this material in human phagocytes.

\section{Materials and methods Subjects}

After obtaining informed consent, a $15 \mathrm{~mL}$ sample of blood was collected from 120 clinically healthy men aged 18-35 years. The study was approved by the local ethics committee.

\section{Preparation of herbal mixture}

The herbal mixture was composed of dry Orbignya martiana leaves (75\%), Tabebuia avellanedae bark (2\%), Arctium lappa leaves (4\%), Rosa centifolia petals (5\%), Maytenus ilicifolia leaves (5\%), Vernonia condensata leaves (5\%), and Thujae occidentalis leaves (4\%). All of the plants were collected and deposited in the herbarium at the Environmental Biodiversity Center, "EcoCerrado" Reserve, Araxá, MG, Brazil (located at latitude $19^{\circ} 36^{\prime} 47,1^{\prime \prime}$ and longitude $47^{\circ} 08^{\prime} 20,9^{\prime \prime}$, at an altitude of $939 \mathrm{~m}$ ). Preparation of the herbal mixture involved mixing followed by maceration and distillation, in accordance with the Brazilian Pharmaceutical Code. ${ }^{16}$

\section{Phytochemical screening}

Phytochemical screening was performed for identification and the indications of the main chemical constituents of this aqueous herbal extract mixture. ${ }^{28}$ The following reagents and chemicals were used: alkaloids with Dragendorff's reagent, flavonoids with metallic magnesium and $\mathrm{HCl}$, saponins with the ability to produce foam, reducing sugars with Fehling's reagent, glycosides with Liebermann's test, tannins with ferric chloride, and polysaccharides with iodine solution.

\section{Fractions of medicinal plant mixture according to gradient polarity}

The original extract of the plant mixture was prepared to obtain the fractions bidirectionally. The dry extract was resuspended in water and subjected to a systematic method of liquid-liquid partition with solvents of crescent polarity (hexane, dichloromethane, ethyl acetate and 1-butanol). Using the cited procedure, semipurification of the substances was performed according to their individual properties. ${ }^{29}$

\section{Preparation and characterization of PEG microspheres}

The microspheres were obtained from PEG 6000 using a modification of the method described by Scott et al. ${ }^{4}$ Briefly, $20 \mathrm{~g}$ of PEG 6000 was suspended in phosphate-buffered saline, diluted with a solution of sodium sulfate to $2 \%$ in phosphatebuffered saline, and incubated at $37^{\circ} \mathrm{C}$ for 45 minutes. After incubation, the PEG microspheres were diluted 3:1 in phosphate-buffered saline, washed twice in phosphatebuffered saline ( $500 \times \mathrm{g}, 5$ minutes), and resuspended in phosphate-buffered saline. The PEG microspheres were obtained by incubating the suspension at $95^{\circ} \mathrm{C}$ for 5 minutes. Subsequently, the PEG microspheres were fluorescencelabeled with a solution of Dylight-488 $(10 \mu \mathrm{g} / \mathrm{mL}$, Pierce, Rockford, IL) overnight at room temperature in dimethylformamide at a 100:1 molar ratio of PEG:Dylight and then analyzed using a fluorescence microscope (Nikon Eclipse E 200, Nikon Corporation, Tokyo, Japan). 


\section{Analysis of PEG microspheres by flow cytometry}

We performed immunofluorescence staining with phycoerythrin (Sigma, St Louis, MO) to assess the ability of PEG microspheres to bind with fluorescent markers and for comparison with polymethylmethacrylate (BD CaliBRITE) microspheres. The PEG microspheres were incubated with $5 \mu \mathrm{L}$ of phycoerythrin $(0.1 \mathrm{mg} / \mathrm{mL})$ in the presence or absence of the herbal mixture for 30 minutes at $37^{\circ} \mathrm{C}$. After incubation, the PEG microspheres were washed twice in phosphate-buffered saline containing bovine serum albumin $\left(5 \mathrm{mg} / \mathrm{mL}, 500 \times \mathrm{g}, 10\right.$ minutes, $\left.4^{\circ} \mathrm{C}\right)$. In all experiments, the PEG microspheres were analyzed by flow cytometry. The study was performed on FACS Calibur (Becton Dickinson San Jose, CA). The mean size of the PEG microspheres was compared with that of BD microspheres $(6 \mu \mathrm{m}$, CaliBRITE 3 beads, Catalog Number 34048) binding or not binding with phycoerythrin. The ratio of the fluorescence intensity of the PEG microspheres was displayed as the geometric mean fluorescence intensity and their size was calculated according to the geometric mean of forward scatter. The experiments were repeated several times, and the data presented in the accompanying figures are from single experiments.

\section{Separation of blood cells}

Venous blood samples were collected into heparinized $(25 \mathrm{U} / \mathrm{mL})$ tubes from 200 male volunteers aged 18-35 years and fractionated using a Ficoll-Paque density gradient (density $1.077 \mathrm{~g} / \mathrm{L}$, centrifugation $160 \times \mathrm{g}, 30$ minutes, Pharmacia, Uppsala, Sweden). This procedure resulted in 98\% pure mononuclear phagocyte preparations as analyzed morphologically by light microscopy. Purified mononuclear phagocytes were resuspended independently in serum-free medium 199 at a final concentration of $2 \times 10^{6}$ cells $/ \mathrm{mL} .{ }^{22}$

\section{Enteropathogenic Escherichia coli strain}

The enteropathogenic $E$. coli used was isolated from the stools of an infant with acute diarrhea (serotype 0111:H2, LA1, eae1, EAF1, bfp1). This material was prepared and adjusted to $10^{7}$ bacteria/mL, as previously described. ${ }^{22}$

\section{Superoxide anion release}

Superoxide anion release was determined by cytochrome $\mathrm{C}$ reduction. ${ }^{22,30}$ Briefly, mononuclear phagocytes and bacteria, in the presence of medicinal plant mixtures alone or adsorbed onto PEG microspheres, were mixed and incubated for 30 minutes until phagocytosis was observed. The cells were then resuspended in phosphate-buffered saline containing
$2.6 \mathrm{mM} \mathrm{CaCl}_{2}, 2 \mathrm{mM} \mathrm{MgCl}{ }_{2}$, and $2 \mathrm{mg} / \mathrm{mL}$ cytochrome $\mathrm{C}$. Next, $100 \mu \mathrm{L}$ suspensions were incubated for 60 minutes at $37^{\circ} \mathrm{C}$ on culture plates. The reaction rates were measured by absorbance at $550 \mathrm{~nm}$, and the results are expressed as $\mathrm{nmol} / \mathrm{O}^{2-}$. All experiments were performed in duplicate or triplicate.

\section{Bactericidal assay}

Microbicidal activity and phagocytosis were evaluated using the acridine orange method described by BellinatiPires et al. ${ }^{31}$ Equal volumes of bacteria and cell suspension, in the presence of the medicinal plant mixture with or without adsorption onto PEG microspheres, were mixed and incubated at $37^{\circ} \mathrm{C}$ for 30 minutes under continuous shaking. Phagocytosis was stopped by incubation in ice. To eliminate extracellular bacteria, the suspensions were centrifuged twice $\left(160 \times \mathrm{g}, 10\right.$ minutes, $\left.4^{\circ} \mathrm{C}\right)$. The cells were resuspended in serum-free medium 199 and centrifuged. The supernatant was discarded, and the sediment was dyed with $200 \mu \mathrm{L}$ of acridine orange $(14.4 \mathrm{~g} / \mathrm{L})$ for one minute. The sediment was resuspended in cold culture medium 199, washed twice, and observed by immunofluorescence microscopy at magnifications of $400 \times$ and $1000 \times$. The phagocytosis index was calculated by counting the number of cells ingesting at least three bacteria in a pool of 100 cells. To determine the bactericidal index, the slides were stained with acridine orange, and 100 cells with phagocytosed bacteria were counted. The bactericidal index was calculated as the ratio between the orange-stained (dead) and green-stained (alive) bacteria $\times 100 .{ }^{31}$ All experiments were performed in duplicate or triplicate.

\section{Statistical analysis}

Analysis of variance was used to evaluate superoxide anion release, phagocytosis, and the bactericidal index in the presence or absence of enteropathogenic $E$. coli for cells with or without incubation with PEG microspheres containing adsorbed nanofractions of the medicinal plant mixture. Statistical significance was set at $P<0.05$.

\section{Results}

\section{Phytochemical screening}

Phytochemical screening showed the presence of tannins, especially a condensed type known as the catechist tannin. The chemical composition of the mixture also contained leucoanthocyanidins, flavanones, and catechins. To a lesser degree, phenols, anthocyanins, proanthocyanidins, flavonoids, flavanones, xanthones, triterpenoids, and saponins were present. 
The herbal mixture showed an absence of steroids, resins, alkaloids, quaternary compounds, quinones, flavonoid aglycones and steroid aglycone triterpenoids (Table 1).

\section{Characterization of PEG microspheres}

Figure 1A shows the fluorescence intensity relationship between the PEG microspheres, PEG microspheres bearing the adsorbed herbal mixture, and standard BD microspheres. The PEG microspheres and BD microspheres had a similar geometric mean fluorescence intensity. PEG microspheres bearing the adsorbed herbal mixture had a lower geometric mean fluorescence intensity. The PEG microspheres bearing or not bearing the adsorbed herbal mixture had a size similar to that of standard BD microspheres (Figure 1B). The fluorescence microscopy image shown in Figure 2A is for PEG microspheres produced in phosphate-buffered saline. These microspheres were very stable and retained their spherical structure without deformation. This result confirms that our method produces microspheres of different sizes in the suspension, with a mean size of $5.8 \mu \mathrm{m}$ (Figures 1B and 2A). Fluorescence microscopy confirmed that the PEG microspheres were able to adsorb the herbal mixture (Figure 2B).

\section{Dose-response curves for herbal plants and their fractions}

The dose-response curves for the herbal plant mixture and its fractions were constructed. To determine the relationship between dosage and response, three different doses of each fraction of herbal mixture were examined. Superoxide release by phagocytes on exposure to the herbal mixture and its fractions was evaluated,

Table I Phytochemical screening for identification and indication of main chemical constituents of aqueous extract of herbal mixture

\begin{tabular}{ll}
\hline Analysis & Aqueous extract \\
\hline Tannins & Present \\
Leucoanthocyanidins, catechins, and flavanones & Present \\
Phenols & Present \\
Anthocyanins, anthocyanidins, and flavonoids & Present \\
Flavanones and xanthones & Present \\
Triterpenoids & Present \\
Saponins & Present \\
Resins & Absent \\
Alkaloids & Absent \\
Quaternary compounds & Absent \\
Quinones & Absent \\
Flavonoids aglycones & Absent \\
Steroid aglycone triterpenoids & Absent \\
\hline
\end{tabular}

Notes: Present, positive reaction; absent, negative reaction.
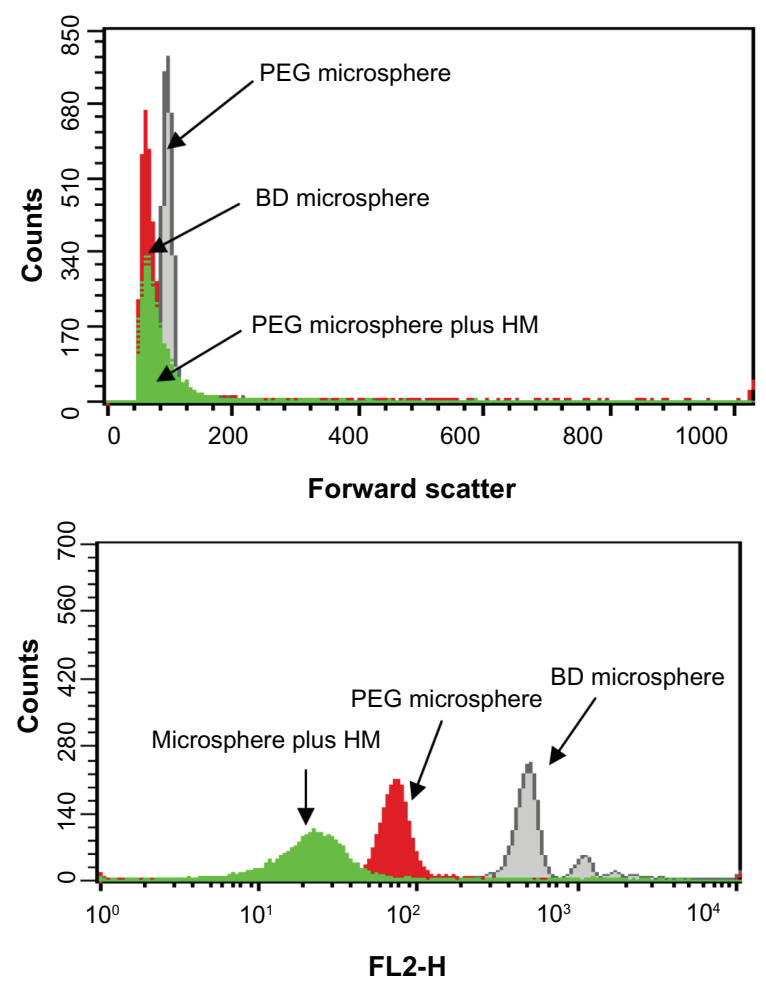

\begin{tabular}{lll}
\hline Microsphere & $\begin{array}{l}\text { Size }- \text { forward } \\
\text { scatter }(\mu \mathrm{m})\end{array}$ & $\begin{array}{l}\text { Fluorescence intensity } \\
(\%, \text { mean } \pm \text { SD) }\end{array}$ \\
\hline BD & 6 & $83.1 \pm 5.1$ \\
PEG & 5.8 & $65.3 \pm 4.7$ \\
PEG + HM & 5.9 & $36.8 \pm 2.5$ \\
\hline
\end{tabular}

Figure I PEG microspheres adsorbed or not with herbal mixture were stained directly with phycoerythrin as described in the Materials and methods section. Notes: Polymethylmethacrylate PE-labeled microspheres were used as standard. Immunofluorescence analysis and size measurement were then carried out by flow cytometry.

Abbreviations: BD, Becton Dickinson; HM, herbal mixture; PEG, poly(ethylene glycol); SD, standard deviation.

and a correlation between dosage and response was observed, with superoxide release increasing according to the size of the dose. Based on the results, we used a test dose of $100 \mathrm{ng} / \mathrm{mL}$ (Figure 3).

\section{Effect of PEG microspheres containing the plant mixture and its fractions on mononuclear phagocytes}

The PEG microspheres and the medicinal plant mixture did not affect the retrieval or viability of the phagocytes. The dichloromethane fraction, when incubated with phagocytes, had a viability index of less than $90 \%$ and was not tested in any further assays of functional cell activity. The other fractions obtained by gradient polarity did not affect cell viability and were tested for functional activation $(P<0.05$, Table 2). 

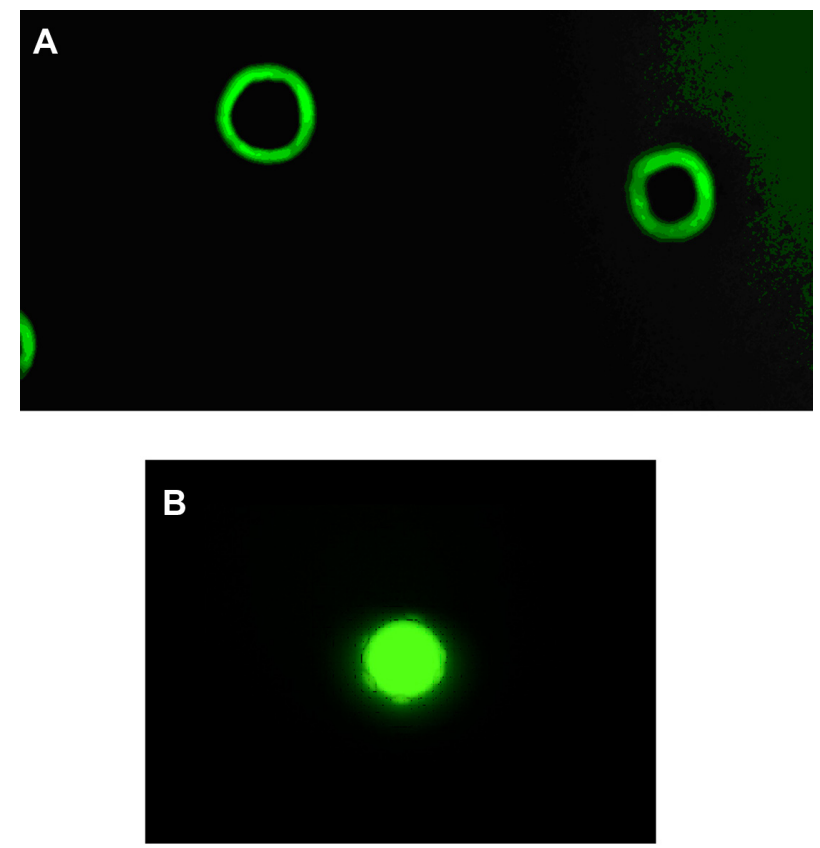

Figure 2 Fluorescence microscopy image (panel A, I00x) of the PEG microspheres stained with Dylight-488. The PEG microspheres were incubated with the herbal mixture (panel $\mathbf{B}, 100 \times$ ) on a shaker for 30 minutes at $37^{\circ} \mathrm{C}$, stained with Dylight-488.

Notes: The microspheres were subsequently analyzed by fluorescence microscopy. Experiments were repeated five times, and the results were comparable. Abbreviation: PEG, poly(ethylene glycol).

\section{Effect of PEG microspheres bearing adsorbed plant extract on superoxide release}

The PEG microspheres increased the release of superoxides from phagocytes when compared with spontaneous phagocyte release. Bacteria in phosphate-buffered saline did not stimulate superoxide release. Phagocytes incubated with bacteria and the herbal plant mixture showed higher superoxide release than did untreated phagocytes $(P<0.05)$. In the presence of bacteria and fractions of

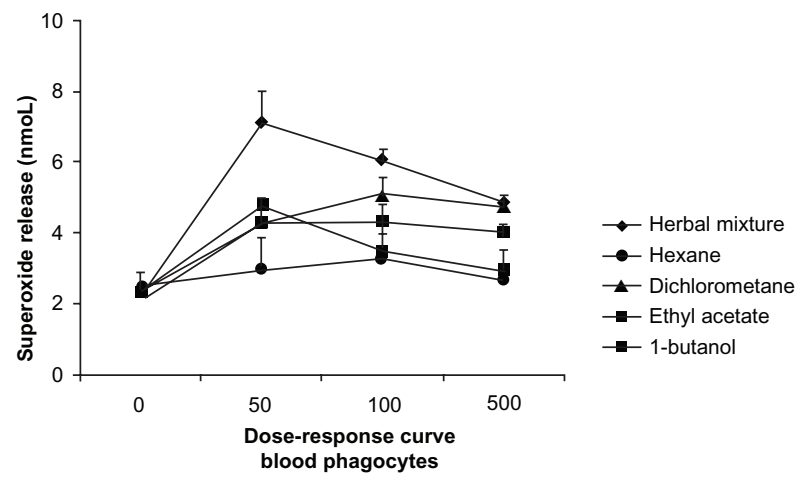

Figure 3 Dose-response curve of superoxide release by blood phagocytes incubated with different doses of the herbal mixture or its fractions obtained by a polarity gradient ( $n=6$ in each treatment).
Table 2 Index of viability (\%) of blood mononuclear phagocytes in the presence of herbal mixture and its fractions

\begin{tabular}{ll}
\hline Experimental group & $\begin{array}{l}\text { Viability of mononuclear } \\
\text { phagocytes (\%) }\end{array}$ \\
\hline 199 medium & $99 \pm 1.2$ \\
Herbal compound & $99 \pm 1.3$ \\
Dichloromethane & $87 \pm 1.4$ \\
Ethyl acetate & $92 \pm 1.3$ \\
I-butanol & $90 \pm 1.2$ \\
\hline
\end{tabular}

Note: Results present the mean \pm standard deviation of ten experiments with cells from different individuals (analysis of variance, $P>0.05$ ).

the herbal mixture, phagocytes showed higher superoxide release than did the untreated phagocytes. Further, in the presence of PEG microspheres bearing the adsorbed herbal plant mixture or its fractions, phagocytes did not show increased release of superoxide when compared with phagocytes exposed only to the herbal plant mixture or its fractions (Table 3).

\section{Effects of PEG microspheres bearing adsorbed plant extract or its fractions on phagocytosis by mononuclear cells}

Phagocytes displayed some scavenging activity in response to enteropathogenic E. coli. Phagocytosis increased significantly in the presence of PEG microspheres. When the phagocytes were stimulated with the herbal mixture or its fractions, an increase in phagocytosis was observed. Comparison of PEG microspheres bearing the adsorbed herbal mixture or its fractions with only the herbal plants or their fractions alone showed that phagocytic activity was similar (Table 4).

Table 3 Superoxide release by blood mononuclear phagocytes (mean \pm standard deviation, $\mathrm{n}=28$ in each treatment)

\begin{tabular}{lc}
\hline Bacteria treatment & Superoxide release $\mathbf{( n m o l )}$ \\
\hline Control & $7.9 \pm 1.3$ \\
(without bacteria) & $7.9 \pm 0.5$ \\
PBS & $9.8 \pm 1.1^{*}$ \\
PEG & $11.3 \pm 1.4^{*,+}$ \\
Herbal compound & $8.9 \pm 0.6^{*}$ \\
Ethyl acetate & $9.4 \pm 0.9^{*}$ \\
I-butanol & $10.2 \pm 0.5^{*,+}$ \\
Herbal compound + PEG & $9.2 \pm 0.4^{*}$ \\
Ethyl acetate + PEG & $9.6 \pm 0.5^{*}$ \\
I-butanol + PEG &
\end{tabular}

Notes: Mononuclear cells were incubated with the herbal mixture and its fractions. In the control assays, the mononuclear cells were preincubated with PBS. *Differences between treatment with control (without bacteria); ${ }^{+}$differences between treatment with herbal plant or its fractions adsorbed with the PEG microspheres with compost not adsorbed (analysis of variance, $P<0.05$ ).

Abbreviations: PBS, phosphate-buffered saline; PEG, poly(ethylene glycol). 
Table 4 Bacterial phagocytosis and the bactericidal activity index from blood mononuclear cells (mean \pm standard deviation, $\mathrm{n}=10$ in each treatment)

\begin{tabular}{lll}
\hline $\begin{array}{l}\text { Experimental } \\
\text { group }\end{array}$ & $\begin{array}{l}\text { Phagocytosis } \\
\text { (\%) }\end{array}$ & $\begin{array}{l}\text { Bactericidal index } \\
\text { (\%) }\end{array}$ \\
\hline Medium 199 & $62.8 \pm 5.0$ & $42.8 \pm 4.9$ \\
PEG & $74.0 \pm 3.5^{*}$ & $57.9 \pm 4.8^{*}$ \\
Herbal extract & $86.8 \pm 2.9^{*}$ & $67.4 \pm 7.1^{*}$ \\
Ethyl acetate & $68.4 \pm 2.2$ & $66.1 \pm 4.2^{*}$ \\
I-butanol & $71.2 \pm 1.5^{*}$ & $62.1 \pm 11.4^{*}$ \\
Herbal extract + PEG & $87.4 \pm 7.4$ & $64.6 \pm 5.3^{*}$ \\
Ethyl acetate + PEG & $73.4 \pm 2.1^{*}$ & $57.2 \pm 5.2^{*}$ \\
I-butanol + PEG & $69.8 \pm 2.7$ & $63.3 \pm 5.1^{*}$ \\
\hline
\end{tabular}

Notes: Bacterial phagocytosis and the elimination index by mononuclear cells from blood were determined with the acridine orange method. *Differences between treatment with herbal plants or fractions adsorbed not with PEG microspheres or 199 medium (analysis of variance, $P<0.05$ ).

Abbreviation: PEG, poly(ethylene glycol).

\section{Effects of PEG microspheres bearing adsorbed plant extract or its fractions on bactericidal activity of phagocytes}

In general, mononuclear phagocytes that were not stimulated had low bactericidal activity against enteropathogenic E. coli. Mononuclear phagocytes incubated with the herbal plant mixture or its fractions with and without adsorption onto PEG microspheres showed increased microbicidal activity in response to enteropathogenic E. coli (Table 4).

\section{Discussion}

In the present study, we produced PEG microspheres bearing an adsorbed herbal mixture and studied their effect on viability, superoxide production, and bactericidal activity in phagocytes in vitro. Particulate systems at the micron and submicron levels have been used increasingly for biomedical applications as a result of their ability to allow cellular drug targeting and/or controlled drug release. ${ }^{32-34}$ Microparticles have been used for many years as controlled release delivery systems for drugs and therapeutic proteins. Moreover, microparticles offer the advantage of delivery of a high payload, especially for hydrophilic drugs. ${ }^{35}$

In this study, analysis by fluorescence microscopy and flow cytometry showed the PEG microspheres to be of a regular size, to be easily separated from a suspension, and to adsorb a herbal mixture easily. The ability of microspheres to form gradients may prove to be useful for achieving better control over the kinetics of protein release. ${ }^{36}$ The literature has reported the use of flow cytometry as an alternative method for analysis and visualization of particles. ${ }^{37,38} \mathrm{In}$ this study, flow cytometry showed that the PEG microspheres were about $5.8 \mu \mathrm{m}$ in size. PEG microspheres are a type of copolymer used for clinical administration of therapeutics because of their capacity to incorporate drugs,${ }^{39}$ their ability to increase the duration of drug exposure or production of other substances, such as enzymes, ${ }^{36}$ and their role as an important signaling vehicle in immunity. ${ }^{40}$ The rate of drug release is controlled by physical and chemical factors and it is important to understand the properties of the releasing medium. ${ }^{41}$

The literature reports the effectiveness of medicinal plants, which has opened the possibility of obtaining new drugs, ${ }^{42,43}$ and that a large number of plants used in traditional healing are often prepared as sophisticated combination products, rather than as used as individual plants. ${ }^{44}$ Several medicinal plants have demonstrated an ability to induce immune system activation in combating disease. ${ }^{45,46}$

In this study, we observed that the interaction between PEG microspheres and phagocytes did not affect cell viability. Superoxide release increased in the presence of the herbal mixture, and the PEG microspheres did not alter this response. Phagocytes incubated with enteropathogenic E. coli in the presence of PEG microspheres bearing the adsorbed herbal mixture showed more superoxide release than phagocytes exposed to bacteria alone. The results of our study confirm the importance of the superoxide anion for bacterial activity and systemic drug delivery. The increase in superoxide release in response to PEG microspheres bearing the adsorbed herbal mixture affected phagocytic and bactericidal activity.

Here, we have found that PEG microspheres bearing an adsorbed herbal mixture have a potent immunostimulatory effect on the functional activity of phagocytes. The same effects were observed for the fractions obtained from the plant mixture. Phagocytes obtained from blood are known to kill enteropathogenic $E$. coli in the presence of herbal mixtures associated with peptides. This interaction may represent an alternative mechanism of defense against infection. ${ }^{15}$

PEG microspheres bearing the adsorbed herbal mixture did not interfere with the functioning of phagocytes, indicating that this polymer could be a transport vehicle for phytopharmaceuticals. Previous studies have shown that PEG has important carrier properties ${ }^{47}$ and promotes uptake of microparticles by macrophages. Such uptake is the result of simultaneous occurrence of a linear nonspecific process and a nonlinear specific and saturable process. The relative contribution of these specific and nonspecific processes to overall uptake by cells varies greatly according to the ligands involved, and is dependent on the particle-to-cell ratio. 
Development of microspheres with suitable ligands could be exploited for increasing drug and antigen targeting to specific cells. ${ }^{48}$

The system of adsorption of plant mixtures onto PEG microspheres described here was effective because the adsorbed microsphere plant mixture and phagocytes were able to bind, the structure could be internalized, and the functional activity of cells was stimulated. This system may be useful for the delivery of a variety of medicinal plants and could provide additional protection against infection.

\section{Conclusion}

In conclusion, PEG microspheres containing an adsorbed natural product as described here represent an alternative for enhancing immune function and could be an option in future clinical applications.

\section{Acknowledgment}

The authors are very grateful to Valeria Conde Correa of the Environmental Biodiversity Center, "EcoCerrado" Reserve, Araxá, MG, Brazil, for technical assistance with the herbal mixture. This research received grants (738264/2008, 301610/2010; 475739/2011-6) from FAPEMAT; CNPq.

\section{Disclosure}

The authors report no conflicts of interest in this work.

\section{References}

1. Ajazuddin SS. Applications of novel drug delivery system for herbal formulations. Fitoterapia. 2010;81:680-689.

2. Ribeiro-Costa RM, Pereira ECG, Alves JA, et al. In vitro and in vivo properties of usnic acid encapsulated into PLGA-microspheres. J Microencapsul. 2004;21:371-384.

3. Park J, Ye M, Park K. Biodegradable polymers for microencapsulation of drugs. Molecules. 2005;10:146-161.

4. Scott EA, Nichols MD, Kuntz-Willits R, Elbert DL. Modular scaffolds assembled around living cells using poly (ethylene glycol) microspheres with macroporation via a non-cytotoxic porogen. Acta Biomater. 2010;6: 29-38.

5. Rodrigues PCA, Roth T, Fiebig HH, Unger C, Mülhaupt R, Kratz F. Correlation of the acid-sensitivity of polyethylene glycol daunorubicin conjugates with their in vitro antiproliferative activity. Bioorg Med Chem. 2006;14:4110-4117.

6. Yu D, Peng P, Dharap SS, Wang Y, Mehlig M, Chandna P. Antitumor activity of poly(ethylene glycol)-camptothecin conjugate: the inhibition of tumor growth in vivo. $J$ Control Release. 2005;110:90-102.

7. Heyes J, Hall K, Tailor V, Lenz R, MacLachlan I. Synthesis and characterization of novel poly(ethylene glycol)-lipid conjugates suitable for use in drug delivery. J Control Release. 2006;112:280-290.

8. Veronese FM, Pasut G. PEGylation, successful approach to drug delivery. Drug Discov Today. 2005;10:1451-1458.

9. Salmaso S, Semenzato A, Bersania S, Chinol M, Paganelli G, Caliceti P. Preparation and characterization of active site protected poly(ethylene glycol)-avidin bioconjugates. Biochim Biophys Acta. 2005;1726: $57-66$.
10. Greenwald RB, Choe YH, McGuire J, Conover CD. Effective drug delivery by PEGylated drug conjugates. Adv Drug Deliv Rev. 2003;55:217-250.

11. Hinds KD, Kim SW. Effects of PEG conjugation on insulin properties. Adv Drug Deliv Rev. 2002;54:505-530.

12. Greenwald RB. PEG drugs: an overview. J Control Release. 2001;74: $159-171$.

13. Alagusundaram M, Chetty CMS, Umashankari K, Badarinath AV, Lavanya C, Ramkanth S. Microspheres as a novel drug delivery system a review. Int J Chem Tech Res. 2009;1:526-534. http://sphinxsai.com/ CTVOL3/CT=22, alagusundaram\%20(526-534).pdf

14. Corrêa VSC, Maynié JC, França EL, Honorio-França AC. Activity of phagocytes in the Presence of the "Mais Vida" (more life) herbal remedy. Braz J Med Plants. 2006;8:26-32. http://www.ibb.unesp.br/home/ departamentos/botanica/rbpm-revistabrasileiradeplantasmedicinais/ artigo5_v8_n2.pdf

15. França EL, Maynie JC, Correa VSC, et al. Immunomodulatory effects of herbal plants plus melatonin on human blood phagocytes. Int $J$ Phytomed.2010;2:345-362. http://www.arjournals.org/index.php/ijpm/ article/view/131

16. França EL, Feliciano ND, Silva KA, Ferrari CKB, Honório-França AC Modulatory role of melatonin on superoxide release by spleen macrophages isolated from alloxan-induced diabetic rats. Bratisl Lek Listy. 2009;110:517-522.

17. França EL, Bitencourt RV, Fujimori M, Morais TC, Calderon IMP, Honorio-França AC. Human colostral phagocytes eliminate enterotoxigenic Escherichia coli opsonized by colostrums supernatant. J Microbiol Immunol Infect. 2011;44:1-7.

18. França EL, Morceli G, Fagundes DLG, Rudge MVC, Calderon IMP, Honorio-França AC. Secretory IgA-Fc $\alpha$ receptor interaction modulating phagocytosis and microbicidal activity by phagocytes in human colostrum of diabetics. APMIS. 2011;119:710-719.

19. Botelho ACF, França JL, Oliveira FC, et al. Melatonin reduces the severity of experimental amoebiasis. Parasit Vectors. 2001;4:62-67.

20. Botelho ACF, França JL, França EL, Honorio-França AC, Busatti HGNO, Gomes MA. Relationship between oxidative stress production and virulence capacity of Entamoeba strains. J Parasitol. 2010;5: 139-147.

21. Ferrari CKB, França EL, Honorio-França AC. Nitric oxide, health and disease. J Appl Biomed. 2009;7:163-173.

22. Honorio-França AC, Carvalho MPSM, Isaac L, Trabulsi LR, CarneiroSampaio MMS. Colostral mononuclear phagocytes are able to kill enteropathogenic Escherichia coli opsonized with colostral IgA. Scand J Immunol. 1997;46:59-66.

23. Honorio-França AC, Launay P, Carneiro-Sampaio MMS, Monteiro RC. Colostral neutrophils express IgA Fc receptors (CD89) lacking $\gamma$ chain association that mediate non-inflammatory properties of secretory IgA. J Leukoc Biol. 2001;69:289-296.

24. Tiwari U, Rastogi B, Singh P, Saraf DK, Vyas SP. Immunomodulatory effects of aqueous extract of Tridax procumbens in experimental animals. J Ethnopharmacol. 2004;92:113-119.

25. Viegas C Jr, Bolzani, VS, Barreiro EJ. The natural products and the modern medicinal chemistry. Quim Nova. 2006; 29:326-337.

26. Patwardhan B, Manish G. Botanical immunodrugs: scope and opportunities. Drug Discov Today. 2005;10:495-502.

27. Mehrotra S, Mishra KP, Maurya R, et al. Anticellular and immunosuppressive properties of ethanolic extract of Acorus calamus rhizome. Int Immunopharmacol. 2003;3:53-61.

28. Harbone JB. Phytochemical methods: In: A Guide to Modern Techniques of Plant Analysis. 2nd ed. London, UK: Chapman and Hall; 1984.

29. Cechinel-Filho V, Yunes RA. Estrategies for obtaining pharmacologically active compounds from medicinal plants: concepts about structural modification for improve the activity. Quim Nova. 1998;21: 99-105.

30. Pick E, Mizel D. Rapid microassays for the measurement of superoxide and hydrogen peroxide production by macrophages in culture using an automatic enzyme immunoassay reader. J Immunol Methods. 1981;46: 211-226. 
31. Bellinati-Pires R, Salgado MM, Hypolito IP, Grumach AS, Carneiro Sampaio MMS. Application of a fluorochromelysostaphin assay to the detection of phagocytic and bacterial disturbances in human neutrophils and monocytes. J Investig Allergol Clin Immunol. 1995;5:337-342.

32. Chavanpatil MD, Khdair A, Panyam J. Nanoparticles for cellular drug delivery: mechanisms and factors influencing delivery. $J$ Nanosci Nanotechnol. 2006;6:2651-2663.

33. Panyam J, Labhasetwar V. Biodegradable nanoparticles for drug and gene delivery to cells and tissue. Adv Drug Deliv Rev. 2003;55: 329-347.

34. O'Hagan DT, Singh M. Microparticles as vaccine adjuvants and delivery systems. Expert Rev Vaccines. 2003;2:269-283.

35. Waeckerle-Men Y, Allmen EU, Gander B, et al. Encapsulation of proteins and peptides into biodegradable poly(d,l-lactide-co-glycolide) microspheres prolongs and enhances antigen presentation by human dendritic cells. Vaccine. 2006;24:1847-1857.

36. Gang R, Si-Shen F. Preparation and characterization of poly (lactic acid)-poly(ethylene glycol)-poly(lactic acid) (PLA-PEG-PLA) microspheres for controlled release of paclitaxel. Biomaterials. 2003;24: 5037-5044.

37. Ai H, Pink JJ, Shuai XT, Boothman DA, Gao JJM. Interactions of polyelectrolyte shells with cells. Biomed Mater Res. 2005;73:303-310.

38. Städler B, Price AD, Zelikin AN. A critical look at multiayered polymer capsules in biomedicine: drug carries, artificial organelles, and cell mimics. Adv Funct Mater. 2011;21:14-28.

39. Novelli ELB, Rodrigues NL, França EL, Gebra LMM, Ribas BO. High dietary carbohydrate and pancreatic lesion. Braz JMed Biol Res. 1993;26: $31-36$
40. Wang XQ, Wenk E, Zhang ZH, Mennel L, Vunjak-Novakovic G, Kaplan DL. Growth factor gradients via microsphere delivery in biopolymer scaffolds for osteochondral tissue engineering. J Control Release. 2009;134:81-90.

41. Freiberg S, Zhu XX. Polymer microspheres for controlled drug release. Int J Pharm. 2004;282:1-18.

42. Calixto JB. Efficacy, safety, quality marketing and regulatory guidelines for herbal medicines (phytotherapeutic agents). Braz J Med Biol Res. 2000;32:179-189.

43. Hasani-Ranjbar S, Larijani B, Abdollah MA. Systematic review of Iranian medicinal plants useful in diabetes mellitus. Arch Med Sci. 2008;4:285-292.

44. Bussmann RW, Meyer AGK, Kuhlman A, Townesmith A. Herbal mixtures in traditional medicine in Northern Peru. J Ethnobiol Ethnomed. 2010;6:2-11.

45. Asgary S, Parkhideh S, Solhpour A, Madani H, Mahzouni P, Rahimi P. Effect of ethanolic extract of Juglans regia L. on blood sugar in diabetesinduced rats. J Med Food. 2008;11:533-538.

46. Honorio-França AC, Marins C, Boldrini F, França EL. Evaluation of hypoglicemic activity and healing of extract from amongst bark of "Quina do Cerrado" (Strychnos pseudoquina ST. HILL). Acta Cir Bras. 2008;23:504-510

47. Chunlei L, Caixia W, Hanyu Y. Liposomal topotecan formulation with a low polyethylene glycol grafting density: pharmacokinetics and antitumour activity. J Pharm Pharmacol. 2012;64:372-382.

48. Brandhonneura N, Chevannea F, Vié V, et al. Specific and non-specific phagocytosis of ligand-grafted PLGA microspheres by macrophages. Eur J Pharm Sci. 2009;36:474-485.
Drug Design, Development and Therapy

\section{Publish your work in this journal}

Drug Design, Development and Therapy is an international, peerreviewed open-access journal that spans the spectrum of drug design and development through to clinical applications. Clinical outcomes, patient safety, and programs for the development and effective, safe, and sustained use of medicines are a feature of the journal, which

\section{Dovepress}

has also been accepted for indexing on PubMed Central. The manuscript management system is completely online and includes a very quick and fair peer-review system, which is all easy to use. Visit http://www.dovepress.com/testimonials.php to read real quotes from published authors.

Submit your manuscript here: http://www.dovepress.com/drug-design-development-and-therapy-journal 